\title{
Multifaceted Approaches to Delineate the Structural and Functional Determinants of Follicle Stimulating Hormone Receptor
}

\author{
SMITA D MAHALE*, SWATI K ACHREKAR and ANTARA A BANERJEE \\ National Institute for Research in Reproductive Health (ICMR), J. M Street, Parel, Mumbai 400 012, \\ India
}

(Received on 11 May 2015; Accepted on 22 May 2015)

\begin{abstract}
The interaction of follicle stimulating hormone (FSH) with its cognate G-protein coupled receptor, the follicle stimulating hormone receptor (FSHR) is crucial for folliculogenesis in females and spermatogenesis in males. This necessitates the delineation of the hormone-receptor interaction in greater detail at the molecular level. Several strategies have been employed over last two decades to delineate the hormone-receptor interaction at structural, molecular and cellular level. Here, we have attempted to summarize the work carried out using synthetic peptides and anti-peptide antibodies corresponding to the predicted potential functional epitopes of FSHR, site-directed mutagenesis, naturally occurring mutations and single nucleotide polymorphisms. The collation of information from the methods discussed will presumably prove to be useful in designing modulators of FSH action and enable better understanding of the involvement of various residues or domains of the receptor in its function. The information will also possibly help in developing predictive markers of ovarian response in women undergoing assisted reproductive techniques.
\end{abstract}

Key Words: FSH Receptor; FSHR Gene; Synthetic Peptides; Antipeptide Antibodies; Site Directed Mutagenesis; Mutation; Polymorphisms

\section{Introduction}

Follicle-stimulating hormone (FSH) is a glycoprotein secreted by the anterior pituitary gland under the pulsatile regulation of gonadotropin releasing hormone (GNRH). It is one of the key hormones for mammalian reproduction and is involved specifically in the gonadal development, oocyte maturation at puberty and gamete production during the reproductive phase of life (Simoni and Nieschlag, 1995; Nieschlag et al., 1999). The other members of the glycoprotein family include: luteinizing hormone (LH), chorionic gonadotropin (CG), and thyroid stimulating hormone (TSH). These heterodimeric glycoprotein hormones share a common $\alpha$-subunit and differ in their unique $\beta$-subunit for a given species that determines receptor specificity (Pierce and Parsons, 1981). However, the biological activity is conferred only by the heterodimers.

FSH elicits its physiological action by binding to its cognate receptor (FSHR), expressed on the granulosa cells in the ovary and Sertoli cells in the testis (Sprengel et al., 1990; Camp et al., 1991; Kelton et al., 1992) to bring about folliculogenesis (Richard and Midgley, 1976) in females and spermatogenesis (Nieschlag et al., 1999) in males. FSHR, along with other glycoprotein hormone receptors (LHCGR/TSHR) form the subgroup of Gprotein-coupled receptors (GPCR), which is characterized by the presence of unusually large extracellular domain (ECD) and a heptahelicle serpentine transmembrane domain (TMD) and a short cytoplasmic intracellular domain (ICD) (Dias and Van Roey, 2001).

*Author for Correspondence: smitamahale@hotmail.com; Tel.No: 022-24192002 
The putative FSHR DNA sequence was first reported in 1989 by Vassart's group, who discovered it while cloning the human TSH receptor (Parmentier et al., 1989). In 1990, Sprengel et al. first cloned the cDNA encoding rat FSHR from testicular cells. Thereafter, the cDNA encoding FSHR from many species including human, monkey, mouse, ovine, bovine, equine and porcine has been isolated and sequenced from testis and ovarian tissues. These studies showed that each species has a single FSHR gene (Minegishi et al., 1991; Kelton et al., 1992; Gromoll et al., 1993; Yarney et al., 1993; Houde et al., 1994; Remy et al., 1995). Based on cDNA synthesis of granulosa and Sertoli cells in various species, the full length FSHR transcript is approximately $2.5 \mathrm{~kb}$ (Gromoll et al., 1993).

Linkage analysis and in situ hybridization of chromosomes revealed that in humans, the FSHR gene is located on chromosome 2p21-p16 (Gromoll et al., 1992; Rousseau-Merck et al., 1993). It is interesting to note that other gonadotropin receptor gene, $L H R$ gene, is also mapped to the same location. However, these two receptor genes share no common band within $1100 \mathrm{~kb}$, suggesting rather large distance between the two genes (Gromoll et al., 1992). The FSHR gene is $192 \mathrm{~kb}$ in size and comprises of ten exons ranging between 69-1234 bp and nine introns, ranging between $108 \mathrm{bp}-15 \mathrm{~kb}$. The exon-intron boundaries follow the GT-AG canonical splice consensus sequence conserved in all exons. The amino acids encoded by these junctions are mostly leucine or isoleucine (Gromoll et al., 1994). The first nine exons of FSHR gene encode the N-terminal part of the extracellular domain (ECD). Exon 10 is large and encodes the C-terminal part of the ECD (hinge region), the trans membrane domain (TMD), and the intracellular domain (ICD) of the receptor.

The human FSHR protein is composed of 695 amino acids (aa), including a signal peptide of 17 aa, leading to a mature protein of 678 aa with a molecular weight of $75 \mathrm{kDa}$ (Minegishi et al., 1991). FSHR is highly conserved among species with an overall homology of about $85 \%$. The TMD shows highest homology. Compared to other gonadotropin receptors, the homology of TMD is still very high ( $\sim 69 \%)$, but it drops to $40 \%$ and $25 \%$ in the ECD and ' $\mathrm{C}$ ' terminal tail, respectively. Binding of FSH to its receptor leads to conformational changes in the receptor protein, resulting in activation of the Gs protein and cyclic AMP (cAMP) production (Zhang et al., 1991). Predominantly, the ICD is coupled to a Gs protein that is responsible for initiating a cascade of intracellular events. cAMP is the main second messenger of FSH action, although an increase in calcium ion influx (Gorczynska et al., 1994) or inositol triphosphate has also been described (Quintana et al., 1994 and Tena-Sempere et al., 1999). The X-ray crystal structure of FSH complex with the ECD of FSHR (Fan and Hendrickson, 2005; Jiang et al., 2012) have immensely contributed in understanding the interaction of FSH with its receptor at the molecular level. Yet certain important aspects of ligand-receptor binding and signal transduction remain unknown, most probably because of lack of structural data for the cryptic hinge region. Moreover, it does not provide information on ligand-induced activation of the receptor leading to steroidogenesis.

Studies with FSHB (Kumar et al., 1997) and FSHR female knockout mice have shown that these female mice are infertile with thin uteri and streak ovaries. But in both the cases the male mice were fertile, although there was a decrease in testicular size and partial spermatogenic failure. These findings clearly demonstrate a crucial function of FSH and its receptor in ovulation and reproduction.

The structure-function relationship of FSHR has been studied using different approaches such as chimeras, synthetic peptides, antipeptide-antibodies and mutagenesis. The use of synthetic peptides and antipeptide antibodies corresponding to the predicted surface exposed regions of FSHR have been used extensively for elucidating the key epitopes involved in hormone binding, signal transduction and bioneutralizing epitopes. Additionally, the advances in molecular biology techniques have assisted the creation of chimeric receptors and ease of performing site directed mutagenesis with commercially available kits. This technique is currently being explored for analyzing the importance of single residues. Since the last decade, studies on naturally occurring mutations 
and single nucleotide polymorphisms (SNPs) of FSHR gene have helped in understanding the genotypephenotype correlation. The in-vitro functional characterization studies of FSHR gene mutations have elucidated the molecular events such as hormone binding, signal transduction and receptor trafficking in response to FSH action. Alternatively, spliced variants of FSHR gene also have been reported in literature and few of them are believed to affect fertility in females (Gerasimova et al., 2010). The present review focuses on different approaches employed to delineate the structural and functional determinants of FSHR.

\section{Synthetic Peptides and Antipeptide Antibodies}

The use of synthetic peptides and antipeptide antibodies corresponding to various regions of a protein enable identification of functionally important epitopes. To study FSH-FSHR interactions at the molecular level as well as for designing modulators of FSH action, this strategy has been extensively employed. Most of these studies were performed before the crystal structure of FSH-FSHR (ECD) was published. The finding from studies where this approach was used has been summarized in Table 1.

The N-terminal extra cellular domain (ECD) has been demonstrated as the primary ligand binding domain and the serpentine transmembrane domain relays the signal downstream for bringing about specific biological effects by the glycoprotein hormone receptors FSHR, LH/CGR and TSHR (GPHRs). Owing to the large size of the receptors of GPHRs, the interaction of ligands FSH, LH/hCG and TSH with their cognate receptors, takes place at several sites in the ECD. The region corresponding to residues 9-30 in the extracellular domain of FSHR is FSHR specific i.e. there is no sequence homology with the other GPHRs. Dattatreyamurty et al. (1992) first reported that a synthetic peptide corresponding to residues 9-30 of FSHR specifically binds to FSH. Further, antipeptide antibodies raised against the region 9-30 were seen to inhibit FSH binding and also the ability of FSH to stimulate the conversion of androstenedione to estradiol in cultured immature rat Sertoli cells (Dattatreyamurty and Reichert, 1993).
Immunization of prepubertal BALB/c male mice with phages displaying the FSHR specific decapeptide (amino acids 18-27) was shown to be an effective and reversible male contraceptive (Remy et al., 1996).

Abdennebi et al. (1999) engineered filamentous phages displaying the peptides 18-27 (A), 25-34 (B) and 29-38 (C). They observed that Anti-C IgG had FSH-like agonistic activity and the peptidic vaccines A and B showed reversible inhibition of ovulation in ewes and impaired fertility in female mice. Further, peptide vaccine immunization (18-38) resulted in maintenance of sexual immaturity in male mice and bucks (Abdennebi et al., 2003). Deletion mutant $S^{9}$ $\mathrm{N}^{30}$ of the mature rFSHR sequence showed impairment in FSH binding and folding due to the loss of cysteine 15, which forms a part of the cysteine cluster of rFSHR (Mann et al., 2000). Immunization with peptide 19-29 in male rats suppressed spermatogenesis (Graf et al., 1997).

Drop in sperm count in adult male bonnet monkeys actively immunized with the phages displaying the peptides 18-27, 25-34 and 27-38 was also reported (Rao et al., 2004). Also, certain residues in the 9-30 stretch were indicated to play a role in hormone-receptor interaction by the partially solved crystal structure of FSH-FSHR complex (Fan and Hendrickson, 2005).

Since the FSHR specific region 9-30 was certainly crucial for FSH-FSHR interaction, overlapping peptides corresponding to the regions 919, 15-25 and 20-30 of rat FSHR were synthesized in order to identify a smaller immuno-dominant epitope within this region (Ghosalkar and Mahale, 2006). Epitope analysis carried out using antibody to 9-30 region showed that the peptide 20-30 displayed maximum binding to the antibody. Next, competitive ELISA was carried out and it was seen that out of the peptides tested, only the peptides 9-30 and 20-30 could inhibit the binding of antibodies against the region 9-30 to the corresponding peptide. Importantly, the inhibition occurred in a dose-dependent manner. Further, a radioreceptor assay (RRA) was carried out to detect the ability of the peptide to inhibit FSH binding. Here too, not only was the peptide 20-30 more 
Table 1: Studies with synthetic peptide and anti-peptide antibodies indicating functionally crucial epitopes of FSHR

\begin{tabular}{|c|c|c|c|}
\hline Peptide region of FSHR & Species & Significant findings & References \\
\hline $9-30$ & Human & Inhibited the binding of FSH to the receptor & Dattatreyamurty et al., 1992, 1993 \\
\hline $9-30,9-19,15-25,20-30$ & Rat & Peptide $20-30$ was more potent & Ghosalkar et al., 2006 \\
\hline $\begin{array}{l}20-30 \text { and its alanine analogs } \\
E^{22}, D^{26}, R^{29}\end{array}$ & Rat & $\begin{array}{l}\text { Charged residues responsible for the peptide } \\
\text { activity }\end{array}$ & Dupakuntla et al., 2009 \\
\hline $18-27$ & Human & $\begin{array}{l}\text { Effective and reversible contraception achieved in } \\
\text { prepubertal BALB/c male mice injected with the } \\
\text { phages displaying thepeptides }\end{array}$ & Remy et al., 1996 \\
\hline $19-29$ & Rat & $\begin{array}{l}\text { Completely inhibited FSH binding. Moreover it } \\
\text { was also observed that there was reduction in } \\
\text { sperm counts in male rats immunized with the } \\
\text { peptide }\end{array}$ & Graf et al.,1997 \\
\hline $18-38$ & Human & $\begin{array}{l}\text { Peptide vaccine immunization resulted in } \\
\text { maintenance of sexual immaturity in male mice } \\
\text { and bucks }\end{array}$ & Abdennebi et al., 2003 \\
\hline $18-27,25-34,27-38$ & Human & $\begin{array}{l}\text { Drop in sperm count in adult male bonnet } \\
\text { monkeys actively immunized with the phages } \\
\text { and impairment in fertility in ewes and female mice }\end{array}$ & $\begin{array}{l}\text { Rao et al., } 2004 \\
\text { Abdennebi } \text { et al., } 1999\end{array}$ \\
\hline $\begin{array}{l}15-31,79-89,171-183 \\
184-195,206-220,216-235 \\
259-274,285-300,297-310 \\
327-341\end{array}$ & Human & $\begin{array}{l}\text { Region 285-300 identified to be crucial for both } \\
\text { FSH binding and cAMP generation. Regions } \\
285-300 \text { and } 327-341 \text { seem to be the chief sites of } \\
\text { FSH binding. Regions } 15-31 \text { and } 216-235 \text { seem } \\
\text { to serve as ancillary FSH-binding sites }\end{array}$ & Kene et al., 2004 and 2005 \\
\hline $221-252$ & Human & $\begin{array}{l}\text { Peptide brings about autologous biological } \\
\text { response modification by associating with and } \\
\text { altering the receptor conformation to an inactive } \\
\text { state }\end{array}$ & Mahale et al., 2001 \\
\hline $265-296$ & Human & $\begin{array}{l}\text { Antipeptide antibody inhibited FSH stimulated } \\
\text { progesterone production }\end{array}$ & Liu et al., 1994 \\
\hline $285-309$ & Rat & $\begin{array}{l}\text { Passive immunization in female rats with anti } \\
285-309 \text { antibodies resulted in infertility in } \\
72 \% \text { indicating that this could be a } \\
\text { bioneutralizating epitope }\end{array}$ & Ghosalkar et al.2007 \\
\hline $300-315$ & Rat & $\begin{array}{l}\text { May constitute FSH binding site via interactions } \\
\text { with FSH residues } \beta 21-35 \text { and } 11-25 \text {. MAb } \\
\text { 106- } 105 \text { detecting this region showed reversible } \\
\text { immunoneutralizing activity against FSHR }\end{array}$ & $\begin{array}{l}\text { Leng et al., } 1995 \\
\text { Lindau-Shepard et al., } 2001\end{array}$ \\
\hline $\begin{array}{l}\text { 405-426 (EL1), 492-511 (EL2), } \\
\text { 581-591 (EL3) }\end{array}$ & , Human & $\begin{array}{l}\text { EL1 and EL3 are surface accessible and probably } \\
\text { act as secondary FSH binding sites }\end{array}$ & Dupakuntlaet al., 2010 \\
\hline
\end{tabular}

effective $\left(\mathrm{IC}_{50}\right.$ value of $\left.0.59 \times 10^{-4}\right)$ than the parent peptide 9-30, a remarkable inhibition of more than $90 \%$ was achieved at the highest dose tested. The mode of inhibition was of mixed type. The other two peptides did not show any inhibition on FSH binding.
The peptide 20-30 was found to inhibit FSH induced cAMP signaling as well (Dupakuntla et al., 2009). Further, alanine substitution analogs of FSHR specific charged residues $\mathrm{E}^{22}, \mathrm{D}^{26}$ and $\mathrm{R}^{29}$ were unable to inhibit FSH binding and FSH induced cAMP response. 
Thus, the charged residues seem to be essential for the antagonistic activity of FSHR peptide 20-30.

Analysis of a peptide corresponding to residues 221-252 which resembled a leucine-rich repeat domain of the FSHR ECD showed that it could inhibit FSH binding to FSHR as well as signal transduction (Mahale et al., 2001). This peptide was proposed to bring about autologous biological response modification by associating with and altering the receptor conformation to an inactive state. Antibodies raised against peptide corresponding to the region 309-322 of human FSHR were shown to inhibit FSH-bioactivity but not LHbioactivity (Zijlstra-Westhoff et al., 1998). Antipeptide antibodies against FSHR $\mathrm{R}^{265}-\mathrm{S}^{296}$ inhibited binding of radio-labeled $\mathrm{hFSH}$ to insect cell rat FSHR indicating the role of those residues in hormone binding (Liu et al., 1994). Studies with a synthetic peptide corresponding to residues $300-315$ of rat FSHR showed it to constitute a FSH binding site via interactions with FSH beta 21-35 and 11-25 residues (Leng $\mathrm{N}$ et al., 1995). Lindau-Shepard et al. in 2001 reported reversible immuno-neutralization of FSHR with the help of a monoclonal antibody 106-105 whose epitope consisted of the region 300-315 of human FSHR.

Several peptides corresponding to the predicted surface oriented regions of ECD of hFSHR namely 15-31, 79-89, 171-183, 184-195, 206-220, 216-235, 259-274, 285-300, 297-310 and 327-341 were generated (Kene et al., 2004). Competitive inhibition studies by radio receptor assay and cAMP assay were carried out using synthetic peptides corresponding to the above mentioned regions. The results revealed that the regions 285-300 and 297-310 of hFSHR are essential for FSH binding and the regions 15-31, 7989, 184-195, 216-235 and 285-300 are essential for FSH-induced cAMP production. Thus, the region 285300 was identified as a discriminatory epitope to be crucial for both FSH binding and cAMP generation. Anti-peptide antibodies to the peptides mentioned above showed that the regions 285-300 and 327-341 of hFSHR appear to be the chief sites of hormone binding whereas the regions 15-31 and 216-235 of hFSHR serve as ancillary FSH-binding sites. Antipeptide antibodies against regions 15-31, 216-235,
285-300 and 327-341 of hFSHR behaved as antagonists and inhibited the production of FSHinduced cAMP levels significantly in a dose dependent manner (Kene et al., 2005a). Circular dichroism analysis revealed a $\beta$-sheet structure for peptide 285 300, 297-310 and 327-341 of hFSHR, consistent with their role in hormone binding. A $\alpha$-helical structure was observed for peptides 15-31 and 216-235, which served as ancillary FSH-binding sites essential for signal transduction (Kene et al., 2005b).

Since the above mentioned in vitro studies suggested the importance of the region 285-300 in hormone binding and signal transduction, further in vivo studies were carried out in a rat model. Antibodies to peptide 285-309 from rat FSHR detected FSHR on rat ovarian granulosa cells as seen by immunohistochemistry (Ghosalkar et al., 2007). Passive immunization of antibodies against the peptide 285309 in female rats resulted in inducing infertility in $72 \%$ of them. Thus the epitope $285-309$ was identified to be a bio-neutralizing epitope.

Binding of FSH occurs at the high affinity leucine rich repeats of the ECD followed by relaying the signal downstream by TMD. This process may involve contacts of the hormone-receptor complex with extracellular loops (ELs), which protrude outside the membrane. Determination of surface accessibility of ELs of FSHR was carried out using antipeptide antibodies against synthetic peptides corresponding to the FSHR-ELs. Flow cytometry experiments revealed that the antibodies against EL1 and EL3 of FSHR were able to detect the corresponding regions on FSHR expressing cells (Dupakuntla et al., 2010). Antipeptide antibodies to EL1 and EL3 could inhibit the binding of the hormone to receptor as seen by RRA and also inhibit cAMP production. Thus, EL1 and EL3 probably serve as secondary FSH binding sites.

\section{Site-Directed Mutagenesis Approach}

Site-directed mutagenesis and chimeric receptor approach has led to the identification of residues or domains crucial for FSH-FSHR interaction. Furthermore, the residues involved in interaction between FSHR and adaptor proteins, residues 
contributing to receptor oligomerization, functional specificity, cell surface trafficking, internalization and various signal transduction pathways could be mapped. Advances in computational modeling methods, availability of several databases like SSFAGPHR(www.ssfa-gphr.de database for semiquantitative Sequence-Structure- and FunctionAnalysis of GPHRs), GRIS (http://gris.ulb.ac.be/, glycoprotein-hormone receptor information system), GPCRDB (http://www.gpcr.org/7tm/,G proteincoupled receptors database), several bioinformatic tools and access to servers like Protein Interactions Calculator (PIC, http://pic.mbu.iisc.ernet.in/) that enable study of several types of interactions like ionic bonds, hydrophobic interactions, hydrogen and disulphide bonds, to name a few, have facilitated better understanding of the structure-function correlation of FSHR.

Braun et al., in 1999, first demonstrated that the ECD of GPHRs confer hormone binding and signaling specificity to the receptor. Chimeric receptors of LRR1-11 of FSHR fused to the TMD of LH-CGR bound FSH and stimulated cAMP, but did not bind hCG. This suggested that the ECD determines the hormone binding specificity for GPCRs. By individual and collective substitutions of the residues, it was shown that N-linked glycosylation of Asn ${ }^{174}$ or $\mathrm{Asn}^{276}$ of ECD was essential for efficient folding of the nascent receptor protein into a conformation that allowed high affinity binding of hormone (Davis et al., 1995). By chimeric receptor approach FSHR ECD/ TMD and C-tail of Drosophila melanogaster LGR2 receptor chimeras were created which showed high basal cAMP levels (Nishi et al., 2002). Constitutive activation of chimeric receptor was probably due to removal of constraint imposed by interaction of extra cellular loops with ECD, thus showing the importance of the extra cellular loops of FSHR.

To delineate the importance of a particular domain the approach employed was to swap the residues in the entire domain with the simplest amino acid alanine (Ala). If any loss-of-function was

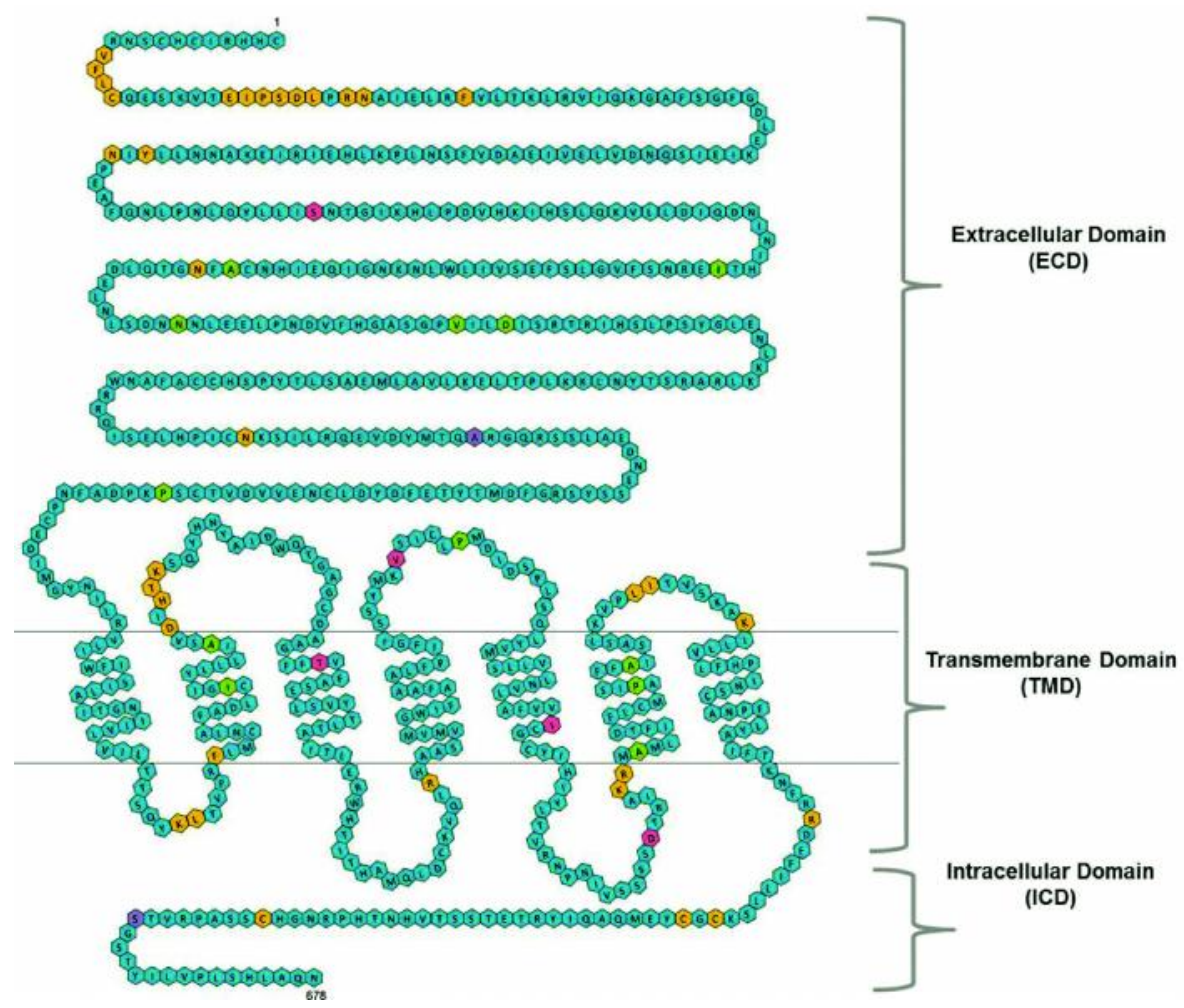

Fig. 1: Sequence of human FSHR. Naturally occurring inactivating mutations ( $\square$ ), activating mutations( $(\square)$ and SNPs $(\square)$ are highlighted. Residues studied using site-directed mutagenesis approach ( $)$ are also indicated. Explanation for each of these residues is provided in the text wherever applicable. The numbering was assigned according to the human sequence, assuming a signal peptide sequence of 17 amino acids 
observed, further Ala scanning mutagenesis of individual amino acids was carried out in order to identify the contribution of side chains of the substituted residue. Deletion and Ala scanning and substitution mutations in the ECD region 9-30 of hFSHR indicated the residues to be essential for FSH binding and signal transduction (Nechamen et al., 2000; Nechamen et $a l ., 2003)$. Individual substitution mutants $\mathrm{V}^{12} \mathrm{~A}$ and $\mathrm{S}^{25} \mathrm{~A}$ showed the $\sim 80 \mathrm{kDa}$ band corresponding to mature FSHR whereas $\mathrm{F}^{13} \mathrm{~A}, \mathrm{~L}^{14} \mathrm{~A}, \mathrm{E}^{22} \mathrm{~A}, \mathrm{I}^{23} \mathrm{~A}$, $\mathrm{D}^{26} \mathrm{~A}, \mathrm{~L}^{27} \mathrm{~A}, \mathrm{R}^{29} \mathrm{~A}$ and $\mathrm{N}^{30} \mathrm{~A}$ showed immature $\sim 62$ $\mathrm{kDa}$ form corresponding to FSHR trapped in the ER. Thus these residues in the ECD are crucial for cell surface trafficking of the receptor. The residues studied by site-directed mutagenesis approach are shown in Fig.1. Ala scan and substitutions of the first five residues in EL1 identified His ${ }^{407}$ to be important for FSH binding as seen by the decreased FSH binding affinity for $\mathrm{His}^{407} \mathrm{Ala}$ mutant and $\mathrm{Asp}^{405}$, $\mathrm{Thr}^{408}$ and Lys $^{409}$ to be essential for cAMP production as the cAMP production was abolished in the Ala substitution mutants of these residues ( $\mathrm{Ji}$ and Ji, 1995). Apart from ECD and EL1, residues in EL3 were shown to influence FSH binding and signal transduction. Binding affinity of $\mathrm{Leu}^{583} \mathrm{Ala}$ or Ile ${ }^{584} \mathrm{Ala}$ mutants was 4-6 fold higher than WT, whereas the cAMP production was abolished for the same (Ryu et al., 1998). Substitution of EL3 residues with a panel of amino acids showed that substitutions/deletion of $\mathrm{Leu}^{583}$ or $\mathrm{Ile}^{584}$ enhanced FSH binding, whereas, substitutions at $\mathrm{Leu}^{583}$, $\mathrm{Ile}^{584}$ and $\mathrm{Lys}^{590}$ abolished cAMP. Substitutions at Lys ${ }^{590}$ also abolished IP3 (Inositol 1,4,5triphosphate) production (Sohn et al., 2002; Sohn et al., 2003). Our group has generated FSHR/LH-CGR extracellular loop chimeras, wherein, the FSHR specific residues from EL1, EL2 and EL3 were swapped with the respective residues from ELs of LH-CGR (Dupakuntla et al., 2012). The EL2 residues in FSHR were found to be important for FSH-FSHR internalization and for FSH-induced cAMP response, whereas the EL3 residues were essential for recycling of FSH-FSHR complex.

The role of intracellular loops and C-tail has been discussed in several studies. Nakamura et al. (1998a and 1998b) showed that rFSHR is phosphorylated at Serine/Threonine residues at IL1 and IL3 but not on
IL2 as seen by the decrease in phosphorylation of the mutants rFSHR-1L ( ${ }^{369} \mathrm{I}, \mathrm{S}^{371} \mathrm{I}, \mathrm{T}^{376} \mathrm{~N}$ of IL1) and rFSHR-3L $\left(\mathrm{T}^{536} \mathrm{~A}, \mathrm{~T}^{541} \mathrm{~A}, \mathrm{~S}^{544} \mathrm{~A}, \mathrm{~S}^{545} \mathrm{~A}, \quad \mathrm{~S}^{546} \mathrm{~A}\right.$, $\mathrm{S}^{547} \mathrm{~A}, \mathrm{~T}^{549} \mathrm{~A}$ of IL3) but not of rFSHR-2L ( $\mathrm{Thr}^{451} \mathrm{Ala}$, $\mathrm{Thr}^{453}$ Val of IL2) in response to FSH stimulation. Further, Krishnamurthy et al. in 2003a proved that association of arrestin-3 ( $\beta$-arrest in 2) with FSHR is dependent on receptor phosphorylation and its over expression can rescue internalization of phosphorylation defective mutants $\mathrm{D}^{389} \mathrm{~N}$ and $\mathrm{Y}^{530} \mathrm{~F}$ (D and $\mathrm{Y}$ are highly conserved residues across GPCRs). IL2 residues (especially $\mathrm{R}^{467}$ which is present in the conserved ERW motif of GPHRs) were found to be essential for Gs coupling and cAMP production (Timossi et al., 2002). Ala scan of IL1 residues revealed that these residues especially $\mathrm{K}^{376}$ are essential for interaction with APPL1 which brings about FSHR-mediated IP3 induction and FSH induced calcium signaling (Thomas et al., 2011). IL3 was identified to be a site of FSHR ubiquitination by a yeast-based interaction trap (Cohen et al., 2003).

Ala substitution of the reversed BBXXB motif (BXXBB) at the IL3 of the hFSHR showed it to be essential for Gos coupling and cAMP production, whereas, the same motif in the $\mathrm{C}$ tail was seen to be more important for membrane expression as the mutations resulted in an immature form of the receptor (Timossi et al., 2004). Confocal microscopy analysis showed that in contrast to the internalized WT receptors which localized only to endosomes, the internalized truncated mutants of C-tail of hFSHR and rFSHR localized to endosomes and lysosomes (Krishnamurthy et al., 2003b). This study showed that most of the FSH-FHSR complex gets recycled back to the cell surface and truncation of eight residues from the C-tail re-route a substantial portion of the internalized FSH-FSHR complex to a degradation pathway. Uribe et al. showed in 2008 that the conserved Cys residues at C-tail $\left(\mathrm{C}^{627 / 629 / 655}\right)$ are important for palmitoylation since the triple mutant $\mathrm{C}^{627 / 629 / 655} \mathrm{~A}$ does not show palmitoylation. Evidence was presented for the crucial role played by the Ser/ Thr cluster in C-tail of rFSHR in phosphorylation and $B$-arrestin recruitment (Kara et al., 2006). FSHR mutants (Ala substitution of the Ser/thr cluster $\mathrm{T}^{638} \mathrm{~A}$, $T^{640} A, S^{641} A, S^{642} A, T^{644} A$ ) showed enhanced 
cAMP production (due to its inability to get desensitized), impaired phosphorylation, $\beta$-arrestin recruitment and hence impaired internalization of FSHFSHR. This study also revealed that FSH induced ERK phosphorylation occurred by two distinct pathways-G $\alpha$ s/PKA-dependent or $\beta$-arrestin dependent.

Several interesting studies have unraveled previously unknown facets of FSHR. Thomas et al. in 2007 first demonstrated that FSHR forms oligomers and undergoes C-terminal proteolytic processing. Trans-activation of non-binding FSHR mutants by a functional FSHR ECD to bring about cAMP or IP production, but not both, was reported by Ji et al. in 2004. Rescue of function of mutants $R^{556} \mathrm{~A}$ (IL3) and $\mathrm{R}^{618} \mathrm{~A}$ (C-tail) by co-transfection with WT fragments of TMD 5,6 or 7 and/or C-tail further substantiated that dimerization of FSHR indeed takes place (Zariñán et al., 2010). Guan et al. (2010) attempted to identify the determinants of FSHR dimerization. BRET experiments revealed that constitutive homodimers of FSHR could be detected in both plasma membrane and ER. They also showed that residues in both the ECD and TMD contribute to homodimerization. Interestingly, BRET experiments using hFSHR-Rluc and hLHR-GFP ${ }^{2}$, hLHR-Rluc and hFSHR-GFP ${ }^{2}$ showed that heterodimerization of FSHR/LHR receptors takes place and these results in attenuation of signaling (Feng et al., 2013). Further to this, a recent study by Mazurkiewicz et al. (2015) has been reported, wherein, Fluorescence Correlation Spectroscopy and Photon Counting Histogram studies showed the presence of freely diffusing FSHR homodimers on the surface of live cells. They also carried out FRET experiments and demonstrated that hFSHR-rLHR-cT (chimera of FSHR and extreme C-tail fluorescent fusion proteins: FSHR-LHRcTYFP/FSHR-LHRcT-mCherrypairs) forms heterodimers/hetero-oligomers with LHR and this possibly occurs during granulosa cell differentiation.

\section{Naturally Occurring Mutations of the FSHR Gene}

Since 1995, several naturally occurring FSHR gene mutations have been reported in the literature, yet these are rare compared to the mutations reported in LHR and TSHR gene (Dufau et al., 1995). The FSHR mutations leading to loss-of-function have been observed in women with ovarian dysgenesis (ODG), primary amenorrhea, and secondary amenorrhea. Such mutations are also reported in men with small testes and impaired spermatogenesis. On the other hand, the mutations causing gain-of-function, have been reported in women with ovarian hyperstimulation syndrome (OHSS) and in a single case of a hypophysectomized man. FSH exhibits its action by binding its receptor followed by signal transduction. These two events of hormone binding and signal transduction are generally studied by in-vitro experiments while characterizing the naturally occurring mutations of FSHR.

The activating and inactivating mutations of FSHR (Fig. 1) are known to provoke potential alterations in receptor function at different stages. Therefore, the functional studies on the naturally occurring mutations have gained importance in understanding the role of key residues involved in ligand interaction, activation and trafficking of the receptor.

\section{Inactivating Mutations}

The first inactivating FSHR mutation was found in several Finnish families after a genetic survey of women with hypergonadotrophic hypogonadism (Aittomaki et al., 1995). Twenty-two of the 72 patients studied carried an identical homozygous loss-offunction $\mathrm{Ala}^{189} \mathrm{Val}$ mutation in the extracellular domain of the FSHR (The numbering was assigned according to the human sequence, assuming a signal peptide sequence of 17 amino acids). Segregation analysis confirmed the autosomic recessive mode of inheritance for the disease and it was mapped on chromosome number 2p, which corresponds to the locus for both FSHR and LHR. In vitro functional studies revealed that although the ligand-binding affinity of the receptor was not affected but its expression on the cell membrane might have been reduced as the MSC-1 cells expressing mutant receptor showed reduced ligand-binding ability. FSH-induced cAMP was observed to be reduced in the mutant receptor when 
compared with the WT receptor. Amino acids from 189 to 193 (AFNGT) in FSHR are conserved across all the glycoprotein hormone receptors and also across all the species. N191 is the proposed glycosylation site and the mutations at position 189 may have an effect on glycosylation and probably on trafficking of mature receptor onto the membrane (Davis et al., 1995).

Thereafter, almost five mutations located in ECD of FSHR, Ile ${ }^{160} \mathrm{Thr}, \mathrm{Asn}^{191} \mathrm{Ile}$, Val ${ }^{221} \mathrm{Gly}, \mathrm{Asp}^{224} \mathrm{Val}$, $\mathrm{Pro}^{348} \mathrm{Arg}$ have been reported (Beau et al., 1998; Tapanainen et al., 1997; Nakamura et al., 2008; Touraine et al., 1999; Allen et al., 2003). It was interesting to note, that, in case of these mutations the ligand binding was mainly affected further leading to either decreased or completely abolished FSH induced cAMP production.

In 2003, Meduri et al. reported a novel mutation $\mathrm{Pro}^{519} \mathrm{Thr}$ in the EL2 of FSHR. This mutation has been observed in a homozygous condition in women with primary amenorrhea. This mutation completely abolished the ligand binding and CAMP production in vitro, due to the defect in the trafficking of receptor. These observations indicate that $\mathrm{Pro}^{519}$ is probably a pre-requisite for the FSHR trafficking and receptor function. Thus, along with ECD, ELs also seem to play an important role in ligand binding and receptor trafficking.

Apart from inactivating mutations identified in the ECD, a number of mutations have been reported in the helices of the TMD of FSHR. A mutation at Ile ${ }^{411}$ Asn position was detected in women with polycystic ovary syndrome (PCOS; Orio et al., 2006). On the other hand, the mutation Pro ${ }^{587} \mathrm{His}$ was observed to lead to more adverse phenotypes such as primary amenorrhea (Kuechler et al., 2010). Recently, our group has also published a novel mutation in the $6^{\text {th }}$ TMD at position 575 leading to a substitution of Ala to Val (Achrekar et al., 2010a) presented by a primary amenorrhea subject. The surface localization of the mutant receptor 575 was observed to be lower as compared to WT receptor. Although the ligand binding ability of the receptor was reported to be decreased, the percentage of receptor internalized was remarkably higher as compared to WT receptor.
These observations indicate defect in trafficking of the mutant receptor to the cell surface. Further, the cAMP levels were almost similar to basal levels even at higher doses of FSH stimulation. This suggests that along with reduced cell surface expression and rapid internalization, the mutation at position 575 resulted in reduced signaling activity of the receptor (Desai et al., 2015). Such studies have helped in establishing a genotype-phenotype correlation and also have contributed in understanding the significance of affected amino acid in FSHR function.

Recently, a novel mutation at position 418 has been reported in a two POF subjects. Both these subjects were found to have a novel pathogenic variant in FSHR (c.1253T>G,p.Ile418Ser), inherited as autosomal recessive trait from heterozygous parents. This loss-of-function mutation is located in exon 10 of FSHR affecting the second trans-membrane helix of the FSHR protein. The trans-membrane domain of FSHR is highly conserved across species and is involved in signal transduction (Katari et al., 2015).

\section{Activating Mutations}

Activating or gain-of-function mutations in the FSHR gene have been reported in both men and women. So far, only two constitutively activating FSHR mutations Asp ${ }^{567}$ Gly and Asn ${ }^{431}$ Ile in male/s have been reported (Casas-González P et al., 2012). Interestingly, in case of $\mathrm{Asn}^{567}$ mutation was reported in a hypophysectomized male, who was under treatment with testosterone. The serum gonadotropin levels in this subject were undetectable; and the subject had normal testis volume and semen parameters. The subject had also fathered three children with testosterone treatment. The mutant receptor displayed three fold higher constitutive activities when studied in vitro and also responded to hCG and TSH treatment (Smits et al., 2003). The second mutation Asn ${ }^{431} \mathrm{Ile}$ was reported in an asymptomatic man. In vitro experiments demonstrated decreased cell surface expression of the mutant receptor. Further, the agonistinduced desensitization and internalization were found to be markedly altered. Both these mutants exhibited ligand-independent constitutive activity when tested in vitro. 
All the activating mutations reported in women so far are associated with spontaneous ovarian hyperstimulation syndrome (sOHSS). These FSHR mutants have been observed to get activated upon hCG/TSH stimulation, suggesting that their ligand specificity could have been affected displaying constitutive activity of the receptor. So far many activating mutations have been reported in women with sOHSS; Asp ${ }^{567}$ Asn (Smits et al., 2003), Thr ${ }^{449}$ Ile (Vasseur et al., 2003), Thr ${ }^{449} \mathrm{Ala}$ (Montanelli et al., 2004), Ile ${ }^{545}$ Thr (De-Leener et al., 2006) and Ser ${ }^{128}$ Tyr (De Leener et al., 2008).

Of these activating mutations, only one (Ser ${ }^{128} \mathrm{Tyr}$ ) is reported from the ECD (De-Leener et $a l ., 2008)$. In contrast to the other mutations, this mutation in the ECD did not show any constitutive activity but exhibited higher affinity and sensitivity toward hCG but not to TSH. Subsequently, the extensive site-directed mutagenesis study at position 128 demonstrated that the increase in the sensitivity to hCG selectively is not a consequence of the loss of serine residue, as some substitutions were found to be neutral (Ser to Ala/His), whereas some substitutions were observed to be sensitive to both hCG and TSH (e.g. Ser to Ile/Val).

So far, all these activating mutations of FSHR have been reported in the subjects who develop sOHSS during first trimester of the pregnancy. However, OHSS is usually a complication of gonadotropin stimulation during in vitro fertilization (IVF) protocol where it is known as iatrogenic OHSS (iOHSS). Recently, our group has published a novel mutation $\mathrm{Val}^{514} \mathrm{Ala}$ in IVF subject undergoing gonadotropin hyper stimulation for super-ovulation. This subject had developed iOHSS. This is the first report of FSHR mutation associated with iOHSS condition. It is noteworthy, that on administration of low amounts of exogenous FSH, the estrogen levels before and after hCG administration were drastically higher in this subject. Due to increased levels of estrogen, the number of pre-ovulatory follicles and retrieved oocytes were very high as expected, leading to development of aOHSS. The functional analysis of mutant receptor 514 was carried out to understand the impact of mutation on receptor activity (Desai et al., 2015). It was observed that the cell surface expression of mutant receptor was very high as compared to the WT receptor. Further, it was observed that the binding of FSH to this mutant receptor was significantly higher as compared to WT receptor, which could be due to the increased cell surface expression of the mutant receptor. On the other hand, the internalization of hormone bound mutant receptor was lower as compared to the WT receptor, leading to significantly low percent internalization index. No distinct differences were observed in the ligand binding characteristics between the mutant and WT FSHR. The basal level of cAMP produced by the cells expressing mutant receptor 514 was higher as compared to WT receptor; however this difference was not significant.

\section{FSHR Gene Polymorphisms and Ovarian Response}

Although FSHR gene is highly polymorphic in nature; the three of the FSHR SNPs-29, 307 and 680 have been studied extensively in different ethnic populations both in male and female. The polymorphisms in the FSHR gene are being studied in relation to ovarian response in various populations. Currently, FSH is being used widely for therapeutic purpose in reproductive medicine and has pharmacogenetic potential for infertility treatment (Casarini and Simoni, 2014). Because of its crucial role in follicle development FSH is being used widely for ovarian stimulation during IVF. Although the protocols used for ovarian stimulations are similar, the ovarian response to exogenous FSH varies widely ranging from poor to hyper-responsive. Many parameters, such as age, diminished ovarian reserve (Klingman and Rosenwaks, 2001) and serum AMH levels (Nardo et al., 2009), have been used as markers to predict the ovarian response. However, determining the dose of FSH to accomplish optimum response is one of the ongoing challenges in the field of infertility management in IVF clinics. Interestingly, FSHR gene polymorphisms have been observed to be associated with aberrant ovarian response.

A breakthrough finding was published in 2000 by Perez-Mayorga et al., demonstrating the role of 
FSHR SNP as a genetic marker to predict ovarian response when they demonstrated that the high serum FSH levels are associated with $\operatorname{Ser}^{680}$ genotype and poor ovarian response in women undergoing IVF. The in-vitro functional analysis of the $\mathrm{Thr}^{307}-\mathrm{Asn}^{680}$ and $\mathrm{Ala}^{307}-\mathrm{Ser}^{680}$ isoforms suggested that the FSH binding and cAMP production is similar for both these isoforms (Tilly et al., 1992; Minegishi et al., 1994; Simoni et al., 1999; Sudo et al., 2002; Nordhoff et al., 2011; Zalewski et al., 2013). Response of these isoforms to TSH stimulation was also characterized in HEK293 cells and was observed to be alike (Ryan et al., 2007). Therefore, the molecular mechanism by which both these polymorphisms might be altering the ovarian response is still unclear. In studies conducted for different ethnic groups, the significantly higher basal FSH levels and lower estradiol production upon hCG stimulation were associated with Ser680 allele (Sudo et al., 2002; de-Castro et al., 2004; Behre et al., 2005; Greb et al., 2005). de-Castro et al. (2004) reported that, other clinical parameters, such as peak E2 levels, number of follicles and oocytes, and amount of exogenous FSH, were observed to be similar in all the three genotypes at position 680 of FSHR although the percent of poor responders were significantly higher in case of women with Ser/Ser genotype.

Moreover, it was noted that in a systematic randomized control study, women with either Ser/Ser or Asn/Asn genotype with 150 or 225IU/day of FSH dose resulted in a similar number of follicles and retrieved oocytes, fertilization rate, and clinical pregnancy (Behre et al., 2005). Furthermore, there are reports from different ethnic origins from Netherlands (Laven et al., 2003; Klinkert et al., 2006) and UK (Mohiyiddeen et al., 2012), which did not report any association of the polymorphism at position 680 with poor ovarian response.

The systematic study of subjects with ODG, poor responders, and good responders demonstrated that subjects with Ser/Ser 680 genotype generate a significantly higher amount of estradiol and higher number of follicles and oocytes when compared with subjects with Asn/Asn genotype (Loutradis et al., 2006). Daelemans et al. (2004) also reported that women with the Ser680 allele were at risk of showing hyper-response when compared with the Asn680 allele. Similarly, our group has observed that although not significant, $50 \%$ of the subjects (three of six subjects) with p.Ser680Ser genotype developed OHSS (Achrekar et al., 2009a).

Recently, a meta-analysis carried out by Morón and Ruiz (2010), and Yao et al. (2011) suggested that the Ser680 allele is the only promising marker available to be used in clinical set-up to predict the ovarian response to FSH stimulation.

Our group recently published a novel observation indicating the association of polymorphism at position 307 with ovarian hyper-response in an Indian population. Almost $85 \%$ of the subjects (six of seven subjects) with $\mathrm{Ala}^{307} \mathrm{Ala}$ genotype were found to be significantly associated with iatrogenic OHSS. These subjects developed OHSS when stimulated with significantly lower amount of exogenous FSH and demonstrated significantly higher levels of estradiol before and on the day of hCG stimulation (Achrekar et al., 2009a). As mentioned earlier, Ala at 307 is linked with the Ser680 allele. Thus, it is more likely that the Ser680 allele along with the Ala307 allele may be associated with hyper-response to FSH stimulation.

The rate of pregnancy in an IVF cycle is very important as it is considered as a measure to determine the IVF outcome. Klinkert et al. (2006) reported that the Ser680 allele is more likely to give a higher pregnancy rate when compared with the Asn ${ }^{680}$ allele. Recently, a genome-wide analysis (GWAS) carried out by Boudjenah et al. (2012) reported that women with Ser/Ser genotype were more likely to have a high response than women with Asn/Asn genotype at position 680 ( 24 vs. $12 \%$ respectively, $\mathrm{P}=0.013$ ). These observations suggest that there is a lack of consistency in the outcome of these association studies and there is a need for clarity in defining the poor ovarian response.

The level of FSHR expression also has an impact on the FSH action. Moreover, the reduced expression of FSHR on GCs has been shown to be associated with poor ovarian response (Cai et al., 2007). The polymorphism at position -29 of the 5' UTR in the 
FSHR gene has been studied with respect to its effect on receptor expression as this polymorphism may modulate the cETS-1 transcription factor binding site. The in vitro analysis carried out in $\mathrm{CHO}$ cells demonstrated that the A-29 allele expressed a significantly lower level of luciferase activity when compared with the G-29 allele of the FSHR gene (Nakayama et al., 2006). Despite the fact that Wunsch et al. (2005) did not observe any association of the polymorphism at position -29 with ovarian response, the clinical parameters considered in this study were limited (basal FSH levels and E2 levels). Recently, we observed that subjects with AA genotype were significantly associated with a reduced number of follicles and retrieved oocytes when compared to subjects with GG genotype. The amount of FSH required for optimum response was also significantly higher in subjects with AA genotype when compared with GG genotype. Almost $66.67 \%$ (odds ratio 8.154; $95 \%$ CI 2.79 to 23.77 ; $\mathrm{P}<0.0001$ ) subjects with AA genotype were poor ovarian responders (Achrekar et al., 2009b; Desai et al., 2011). Further, using granulosa cells (GCs) obtained from women undergoing IVF, we observed that subjects with AA genotype expressed significantly reduced FSHR expression both at transcript and protein level when compared with GG genotype (Desai et al., 2011). This study provides the experimental evidence to suggest that reduced receptor expression observed in subjects with AA genotype could be the probable reason for the poor ovarian response to $\mathrm{FSH}$ stimulation observed in them. However, a greater number of subjects from various ethnic populations need to be analyzed to assess the usefulness of screening this polymorphism, which could be used as a biomarker to predict poor ovarian response.

\section{FSHR Gene and Alternatively Spliced Variants}

In humans, alternate splicing of exon 9 in normal testicular tissue has been reported, which suggests that this spliced variant does not affect the FSHR function in testis (Gromoll et al., 1992). Deletion of exons 6 and 9 and insertion of part of intron 8 has also been identified in infertile men (Song et al., 2002). Additionally, a number of spliced variants such as del exon 2, 6 and 9 and insertion of 102bp of intron 8 along with the WT FSHR in the granulosa cells obtained from women undergoing IVF has also been reported. The clinical parameters of these women suggested that deletion of exon 2 was associated with poor ovarian response whereas deletion of exon 6 was associated with a high response (Gerasimova et $a l ., 2010)$. In our study, in subjects undergoing IVF, we observed that out of a total of 20 subjects screened, only one subject was identified with insertion of a part of intron 8 (102bps) along with the WT-FSHR. However, this spliced variant did not seem to affect the various clinical parameters. To verify the role of these splice variants in ovarian response and female infertility, screening of these variants in large number of subjects is essential.

\section{Association of FSHR SNPs and PCOS, POF and Amenorrhea}

Polycystic ovary syndrome (PCOS) is known as a common endocrine disorder among women of reproductive age. The prevalence of PCOS is around $5-10 \%$ and the clinical manifestation of the disease is diverse. The characteristics of PCOS mainly include oligomenorrhea or amenorrhea, hyperandrogenism and polycystic ovary morphology. The pathogenesis of PCOS is not fully understood. However, the influence of heredity and environment is considered to be the potential causative factors for the disease. In these subjects, LH:FSH ratio is generally increased and there is excessive production of androgen (Goodarzi et al., 2011). So far, studies revealed that there are multiple susceptibility genes associated with PCOS, including growth hormone receptor exon 3 (Shen et al., 2011); CYP11A1 (Zhang et al., 2012) and GnRH (Valkenburg et al., 2009). Recently, a study from Bahrain revealed the association of novel intron specific FSHR (rs11692782) SNP with PCOS, suggesting, that the differential association of FSHR variants with PCOS might be due to the racial/ethnic variation (Almawi et al., 2015). A meta-analysis across the eight studies suggested that the Asp680 allele is associated with lower risk and the Ala307Ser680 genotype is associated with an increased risk of developing PCOS (Du et al., 2010). 
Usually, treatment of infertility in cases with PCOS is based on increasing the level of FSH either by antagonizing the effect of estrogen by clomiphene citrate (CC) or by administrating recombinant FSH (rFSH). Recently, it was observed that subjects with Ser/Ser genotype at position 680 exhibited high resistance to $\mathrm{CC}$ treatment but showed the most favorable response to $\mathrm{rFSH}$ stimulation (Overbeek $e t$ al., 2009). Likewise, in a study with PCOS women from Italy, Asn/Thr genotype at position 307 displayed higher response to FSH stimulation when compared with both the homozygous genotypes (Dolfin et al., 2011).

Premature ovarian failure (POF) is also referred to as primary ovarian insufficiency (POI) and is characterized by low levels of gonadal hormones (estrogen, inhibin) and elevated levels of FSH with impaired ovarian folliculogenesis. The phenotype of the FSHR knockout mice was observed to be similar as observed in POF (Dierich et al., 1998). Thus, FSHR could serve as a strong candidate gene responsible for the phenotype observed in the females with POF. Although there are no clear associations observed in FSHR gene polymorphism with POF, recently Kim et al. (2011) reported that epistasis between FSHR and CYP19A1 polymorphisms was significantly associated with POF.

In the case of subjects with amenorrhea, an association with the Ser680 allele has been observed (Sudo et al., 2002). Recently, our group has investigated the association of polymorphisms at position $-29,307$ and 680 in women with primary and secondary amenorrhea. We observed that in the subjects with primary amenorrhea, AA genotype at position -29 was significantly associated with increased basal serum FSH levels when compared with GG and GA genotype. We have also reported a novel homozygous inactivating mutation at position 575 (Achrekar et al., 2010). Further, we have observed that the mutant receptor 575 showed lower cell surface expression and higher internalized hormone receptor complex. Additionally, a dosedependent increase in the cAMP accumulation was not observed in the case of this mutant as compared with WT (Desai et al., 2015).

\section{FSHR Gene Polymorphisms and Male Infertility}

Since the last decade, several reports have been published on the studies of FSHR gene SNPs and its association with the factors that are evaluated examining the male fertility such as sperm motility, sperm counts and testicular volume. Most of the reports showed no significant association of the polymorphisms at position $-29,307$ and 680 with these parameters (Ahda et al., 2005; Pengo et al., 2006; Li et al., 2011; Lindgren et al., 2012). The recent three meta-analyses that summarized the seven original papers also suggest no association of these polymorphisms with reproductive abnormalities in men (Tüttelmann et al., 2007; Lend et al., 2010; Wu et al., 2012). However, it was interesting to note that subjects with AA genotype at position -29 showed significantly smaller mean testicular volumes when compared with subjects with GG genotype (Lend et al., 2010). Altogether, the reports from different populations suggest that FSHR genotype may not have a significant impact on male reproductive physiology.

\section{FSHR Gene Polymorphisms and Gonadal Cancer}

There are limited studies reported on FSHR gene SNPs and ovarian or testicular cancer. Contradicting observations with respect to the association of FSHR polymorphisms with low or high risk of forming gonadal cancers have been reported. Ala307/Ser680 allele alone or in combination with G-29/T-114 allele was observed to be associated with lower risk of developing testicular cancer (Ferlin et al., 2008). On the other hand, homozygous Ala307/Ser680 alleles have been associated with higher risk and recurrence of developing ovarian cancer (Ludwig et al., 2009). However, the mechanism by which these alleles could modulate the FSHR function in ovarian or testicular cancer cells still remains unknown and holds a great research interest.

Recently, in 2006 it was reported that, the two FSHR SNPs might affect the susceptibility of women to specific subtypes of ovarian cancer. Different types of ovarian cancer might adopt distinct carcinogenetic pathways. Such understanding may be important in selecting patients for ovulation induction therapy (Yang et al., 2006). 


\section{Conclusion}

In this review, we have discussed newer insights with reference to structure, function and molecular biology of FSHR. Specific emphasis was on approaches like synthetic peptides, antipeptide-antibodies, site-directed mutagenesis, naturally occurring mutations and polymorphisms. Studies on synthetic peptides have been gaining importance because of its potential in developing small molecules and structure-based design of agonists or antagonist. Antipeptide antibody studies have proved to be significant in identifying the bioneutralizing epitopes, in understanding the FSHFSHR interactions at the molecular level as well as for designing modulators of FSH action. The naturally occurring mutation studies are helping to understand the functional significance of mutated residue. The in-vitro analysis for characterizing the mutants helps in understanding genotype-phenotype correlation. Studying the SNPs of the FSHR gene is evolving as an important support for pharmacogenomics and personalized medicine and needs to be explored further to optimize the dose of FSH required for superovulation and also to predict the ovarian response in women undergoing FSH treatment in the IVF set up.

\section{Acknowledgements}

The studies mentioned in this review, from authors laboratory were funded through ICMR (NIRRH/1R/ 265/05-2015 and BIC/12(05)/2013), DST and DAEBRNS. We would like to thank Mr. Vaibhav Shinde for preparing Fig. 1 included in this review.

\section{References}

Abdennebi L, Couture L, Grebert D, Pajot E, Salesse R and Remy J J (1999) Generating FSH antagonists and agonists through immunization against FSH receptor N-terminal decapeptides J Mol Endocrinol 22 151-159

Abdennebi L, Chun E Y, Jammes H, Wei D and Remy J J (2003) Maintenance of sexual immaturity in male mice and bucks by immunization against $\mathrm{N}$-terminal peptides of the follicle-stimulating hormone receptor Biol Reprod 68323 327

Achrekar S K, Modi D N, Desai S K, Mangoli V S, Mangoli R V and Mahale S D (2009a) Follicle-stimulating hormone receptor polymorphism (Thr307Ala) is associated with variable ovarian response and ovarian hyper stimulation syndrome in Indian women.Fertil Steril 91 432-439

Achrekar S K, Modi D N, Desai S K, Mangoli V S, Mangoli R V and Mahale S D (2009b) Poor ovarian response to gonadotrophin stimulation is associated with FSH receptor polymorphism. Reprod Biomed Online 18 509-515

Achrekar S K, Modi D N, Meherji P K, Patel Z M and Mahale S D (2010) Follicle stimulating hormone receptor gene variants in women with primary and secondary amenorrhea J Assist Reprod Gene 27 317-326

Ahda Y, Gromoll J, Wunsch A, Asatiani K, Zitzmann M, Nieschlag E and Simoni M (2005) Follicle-stimulating hormone receptor gene haplotype distribution in normozoospermic and azoospermic men J Androl 26 494-499

Aittomäki K, Lucena J L, Pakarinen P, Sistonen P, Tapanainen J, Gromoll J, Kaskikari R, Sankila E M, Lehväslaiho H, Engel AR, Nieschlag E, Huhtaniemi I and de la Chapelle A (1995) Mutation in the follicle-stimulating hormone receptor gene causes hereditary hypergonadotropic ovarian failure Cell 82959-968

Allen L A, Achermann J C, Pakarinen P, Kotlar T J, Huhtaniemi I T, Jameson J L, Cheetham T D and Ball S G (2003) A novel loss of function mutation in exon 10 of the FSH receptor gene causing hypergonadotrophichypogonadism: clinical and molecular characteristics Hum Reprod 18251 256

Almawi W Y, Hubail B, Arekat D Z, Al-Farsi S M, Al-Kindi S K, Arekat M R, Mahmood N, Madan S (2015) Leutinizing hormone/choriogonadotropin receptor and follicle stimulating hormone receptor gene variants in polycystic ovary syndrome $J$ Assist Reprod Genet 32 607-14

Beau I, Touraine P, Meduri G, Gougeon A, Desroches A, Matuchansky C, Milgrom E, Kuttenn F andMisrahi M (1998) A novel phenotype related to partial loss of function mutations of the follicle stimulating hormone receptor $J$ Clin Invest 102 1352-1359

Behre H, Greb R, Mempel A, Sonntag B, Kiesel L and Kaltwasser $P$ (2005) Significance of a common single nucleotide polymorphism in exon 10 of the follicle-stimulating hormone (FSH) receptor gene for the ovarian response to FSH: a pharmacogenetic approach to controlled ovarian hyperstimulation Pharmacogenet Genomics 15 451-456

Boudjenah R, Molina-Gomes D, Torre A, Bergere M, Bailly M, Boitrelle F, Taieb S, Wainer R, Benahmed M and de Mazancourt P (2012) Genetic polymorphisms influence the ovarian response to $\mathrm{rFSH}$ stimulation in patients undergoing in vitro fertilization programs with ICSI PLoS ONE 8700

Braun T, Schofield P R and Sprengel R (1991) Amino-terminal 
leucine-rich repeats in gonadotropin receptors determine hormone selectivity EMBO J 10 1885-1890

Cai J, Lou H, Dong M, Lu X E, Zhu Y M, Gao H J and Huang H $\mathrm{F}$ (2007) Poor ovarian response to gonadotropin stimulation is associated with low expression of follicle-stimulating hormone receptor in granulosa cells Fertil Steril 87 13501365

Camp T A, Rahal J O and Mayo K E (1991) Cellular localization and hormonal regulation of follicle-stimulating hormone and luteinizing hormone receptor messenger RNAs in the rat ovary Mol Endocrinol 51405-1417

Casarini L and Simoni M (2014) Gene polymorphisms in female reproduction Methods Mol Biol 1154 75-90

Casas-González P, Scaglia H E, Pérez-Solís M A, Durand G, Scaglia J, Zariñán T, Dias J A, Reiter E and Ulloa-Aguirre A (2012) Normal testicular function without detectable follicle-stimulating hormone. A novel mutation in the follicle-stimulating hormone receptor gene leading to apparent constitutive activity and impaired agonist-induced desensitization and internalization Mol Cell Endocrinol $36471-82$

Cohen B D, Bariteau J T, Magenis L M and Dias J A (2003) Regulation of follitropin receptor cell surface residency by the ubiquitin-proteasome pathway Endocrinology 144 4393-4402

Daelemans C, Smits G, de Maertelaer V, Costagliola S, Englert Y and Vassart G (2004) Prediction of severity of symptoms in iatrogenic ovarian hyperstimulation syndrome by folliclestimulating hormone receptor Ser680Asn polymorphism J Clin Endocrinol Metab 89 6310-6315

Dattatreymurty B and Reichert L E Jr (1992) A synthetic peptide corresponding to amino acids (9-30)of extra cellular domain of the follitropin (FSH) receptor specifically binds $F S H$ Mol Cell Endocrinol 87 9-17

Dattatreyamurty B and Reichert LE Jr (1993) Functional properties of polyclonal antibodies raised against the $\mathrm{N}$ terminus region (residues 9-30) of the follicle-stimulating hormone (FSH) receptor: significance of this receptor region in $\mathrm{FSH}$ recognition and signal transduction Endocrinology 133 1593-1601

Davis D, Liu X and Segaloff D L (1995) Identification of the sites of N-linked glycosylation on the follicle-stimulating hormone (FSH) receptor and assessment of their role in FSH receptor function Mol Endocrinol 9 159-170

de-Castro F, Morón F J, Montoro L, Galán J J, Hernández D P, Padilla E S, Ramírez-Lorca R, Real L M and Ruiz A(2004) Human controlled ovarian hyperstimulation outcome is a polygenic trait Pharmacogenetics 14 285-293
De Leener A, Montanelli L, Van Durme J, Chae H, Smits G, Vassart G and Costagliola S (2006) Presence and absence of follicle-stimulating hormone receptor mutations provide some insights into spontaneous ovarian hyperstimulation syndrome physiopathology $J$ Clin Endocrinol Metab 91 $555-562$

De Leener A, Caltabiano G, Erkan S, Idil M, Vassart G, Pardo L and Costagliola $S$ (2008) Identification of the first germline mutation in the extra cellular domain of the follitropin receptor responsible for spontaneous ovarian hyperstimulation syndrome Hum Mutat 29 91-98

Desai S S, Achrekar S K, Pathak B R, Desai S K, Mangoli V S, Mangoli R V and Mahale S D (2011) Follicle-stimulating hormone receptor polymorphism (G-29A) is associated with altered level of receptor expression in granulosa cells J Clin Endocrinol Metab 96 2805-2812

Desai S S, Roy B S and Mahale S D (2013) Mutations and polymorphisms in FSH receptor: functional implications in human reproduction Reproduction 146 235-248

Desai S S, Achrekar S K, Sahasrabuddhe KA, Meharji P K, Desai S K, Mangoli V S and Mahale S D (2015) Functional characterization of two naturally occurring mutations (Functional characterization of two naturally occurring mutations (val(514)ala and ala(575)val) in folliclestimulating hormone receptor J Clin Endocrinol Metab 100 E638-45

Dias J A and Van Roey P (2001) Structural biology of human follitropin and its receptor.Arch Med Res32510-519

Dierich A, Sairam R, Monaco L, Fimia M, Gansmuller A, LeMeur $\mathrm{M}$ and Sassone-Corsi P (1998) Impairing folliclestimulating hormone (FSH) signaling in vivo: targeted disruption of the FSH receptor leads to aberrant gametogenesis and hormonal imbalance PNAS 9513612 13617

Dolfin E, Guani B, Lussiana C, Mari C, Restagno G and Revelli A (2011) FSH-receptor Ala307Thr polymorphism is associated to polycystic ovary syndrome and to a higher responsiveness to exogenous FSH in Italian women J Assis Reprod Genet 28 925-930

Du J, Zhang W, Guo L, Zhang Z, Shi H, Wang J, Zhang H, Gao L, Feng G and He L (2010) Two FSHR variants, haplotypes and meta-analysis in Chinese women with premature ovarian failure and polycystic ovary syndrome Mole Genet Metabol 100 292-295

Dufau L, Tsai-Morris H, Hu Z and Buczko E (1995) Structure and regulation of the luteinizing hormone receptor gene $J$ Steroid Biochem Mol Biol 53 283-291

Dupakuntla M, Ghosalkar J D and Mahale S D (2009) 
Characterization of the peptide 20-30 of follicle stimulating hormone receptor as an antagonist of receptor activity: significance of charged residues Chem Biol Drug Des $\mathbf{7 3}$ 108-114

Dupakuntla M and Mahale SD (2010) Accessibility of the extra cellular loops of follicle stimulating hormone receptor and their role in hormone-receptor interaction $\mathrm{Mol}$ Cell Endocrinol 315 131-137

Dupakuntla M, Pathak B, Roy B S and Mahale S D (2012) Extracellular loop 2 in the FSH receptor is crucial for ligand mediated receptor activation $\mathrm{Mol}$ Cell Endocrinol 362 6068

Fan Q R and Hendrickson W A (2005) Structure of human folliclestimulating hormone in complex with its receptor Nature $433269-77$

Feng X, Zhang M, Guan R and Segaloff D L (2013) Heterodimerization between the lutropin and follitropin receptors is associated with an attenuation of hormonedependent signaling Endocrinology 154 3925-3930

Ferlin A, Pengo M, Selice R, Salmaso L, Garolla A and Foresta C (2008) Analysis of single nucleotide polymorphisms of FSH receptor gene suggests association with testicular cancer susceptibility Endocrine-Related Cancer 15 429437

Gerasimova T, Thanasoula M N, Zattas D, Seli E, Sakkas D and Lalioti M D (2010) Identification and in vitro characterization of follicle stimulating hormone (FSH) receptor variants associated with abnormal ovarian response to FSH J Clin Endocrinol Metab 95 529-536

Ghosalkar J D and Mahale S D (2006) Detailed analysis of the region 9-30 of rat follicle stimulating hormone receptor: identification of peptide $20-30$ as a potential hormone binding inhibitor Peptides 27 2894-2900

Ghosalkar J D, Dharma S J, Nandedkar T D and Mahale S D (2007) Identification of the region 285-309 of follicle stimulating hormone receptor as a bioneutralizing epitope J Reprod Immunol 74 24-33

Goodarzi M O, Dumesic D A, Chazenbalk G and Azziz R (2011) Polycystic ovary syndrome: etiology, pathogenesis and diagnosis Nature Reviews Endocrinol 7 219-231

Gorczynska E, Spaliviero J and Handelsman D J (1994) The relationship between 3',5'- cyclic adenosine monophosphate and calcium in mediating folliclestimulating hormone signal transduction in Sertoli cells Endocrinology 134 293-300

Graf K M, Dias J A and Griswold M D (1997) Decreased spermatogenesisas a result of an induced autoimmune reaction directedagainst the gonadotropin receptors in male rats $J$ Androl 18 174-185

Greb R R, Grieshaber K, Gromoll J, Sonntag B, Nieschlag E, Kiesel Land Simoni M (2005) A common single nucleotide polymorphism in exon 10 of the human follicle stimulating hormone receptor is a major determinant of length and hormonal dynamics of the menstrual cycle J Clin Endocrinol Metab 90 4866-4872

Gromoll J, Gudermann T and Nieschlag E (1992) Molecular cloning of a truncated isoform of the human follicle stimulating hormone receptor Biochem Biophys Res Commun 188 1077-1083

Gromoll J, Dankbar B, Sharma R S and Nieschlag E (1993) Molecular cloning of the testicular follicle stimulating hormone receptor of the non human primate Macacafascicularis and identification of multiple transcripts in the testis Biochem Biophys Res Commun 196 1066-1072

Gromoll J, Dankbar B and Gudermann T (1994) Characterization of the 5' flanking region of the human follicle-stimulating hormone receptor gene Mol Cell Endocrinol 102 93-102

Guan R, Wu X, Feng X, Zhang M, Hébert T E and Segaloff D L (2010) Structural determinants underlying constitutive dimerization of unoccupied human follitropin receptors Cell Signal 22 247-256

Houde A, Lambert A, Saumande J, Silversides D W and Lussier J G (1994) Structure of the bovine follicle-stimulating hormone receptor complementary DNA and expression in bovine tissues Mol Reprod Dev 39 127-135

Ji I and Ji T H (1995) Differential roles of exoloop 1 of the human follicle-stimulating hormone receptor in hormone binding and receptor activation J Biol Chem 270 15970-15973

Ji I, Lee C, Jeoung M, Koo Y, Sievert G A and Ji T H (2004) Trans-activation of mutant follicle-stimulating hormone receptors selectively generates only one of two hormone signals Mol Endocrinol 18 968-978

Jiang X, Liu H, Chen X, Chen P H, Fischer D, Sriraman V, Yu H N, Arkinstall S and He X (2012) Structure of folliclestimulating hormone in complex with the entire ectodomain of its receptor Proc Natl Acad Sci USA 109 12491-12496

Kara E, Crépieux P, Gauthier C, Martinat N, Piketty V, Guillou F and Reiter E (2006) A phosphorylation cluster of five serine and threonine residues in the $\mathrm{C}$-terminus of the follicle-stimulating hormone receptor is important for desensitization but not for beta-arrestin-mediated ERK activation Mol Endocrinol 20 3014-3026

Katari S, Wood-Trageser M A, Jiang H, Kalynchuk E, Muzumdar R, Yatsenko S A, Rajkovic A (2015) Novel Inactivating Mutation of the FSH Receptor in Two Siblings of Indian 
Origin with Premature Ovarian Failure J Clin Endocrinol Metab 15 [Epub ahead of print]

Kelton CA, Cheng S V, Nugent N P, Schweickhardt R L, Rosenthal J L, Overton S A, Wands G D, Kuzeja J B, Luchette C A and Chappel S C (1992) The cloning of the human follicle stimulating hormone receptor and its expression in COS7, CHO, and Y-1 cells Mol Cell Endocrinol 89 141-151

Kene P S, Nalavadi V C, Dighe R R, Iyer K S and Mahale S D (2004) Identification of the structural and functional determinants of the extracellular domain of the human follicle stimulating hormone receptor $J$ Endocrinol 182 501-518

KeneP S, Dighe R R and Mahale S D (2005a) Delineation of regions in the extra cellular domain of follicle-stimulating hormone receptor involved in hormone binding and signal transduction Am J Reprod Immunol 54 38-48

Kene P S, Behere D V and Mahale S D (2005b) Secondary structure analysis of synthetic peptides of the extracellular domain of the human follicle-stimulating hormone receptor J Pept Res 66 375-381

Kim S, Pyun J A, Cha D H, Ko J J and Kwack K (2011) Epistasis between FSHR and CYP19A1 polymorphisms is associated with premature ovarian failure Fertil Steril 95 2585-2588

Klingman I and Rosenwaks Z (2001) Differentiating clinical profiles: predicting good responders, poor responders, and hyper responders Fertil Steril 76 1185-1190

Klinkert E R, Velde E R, Weima S, van-Zandvoort P M, Hanssen R G, Nilsson P R, de-Jong FH , Looman C W and Broekmans F J (2006) FSH receptor genotype is associated with pregnancy but not with ovarian response in IVF Reprod Biomed Online 13 687-695

Krishnamurthy H, Galet C and Ascoli M (2003a) The association of arrestin-3 with the follitropin receptor dependson receptor activation and phosphorylation $\mathrm{Mol}$ Cell Endocrinol 204 127-140

Krishnamurthy H, Kishi H, Shi M, Galet C, Bhaskaran RS, Hirakawa T and Ascoli M (2003b) Postendocytotic trafficking of the follicle-stimulating hormone (FSH)-FSH receptor complex Mol Endocrinol 17 2162-2176

Kuechler A, Hauffa B P, Köninger A, Kleinau G, Albrecht B, Horsthemke B and Gromoll J (2010) An unbalanced translocation unmasks a recessive mutation in the folliclestimulating hormone receptor (FSHR) gene and causes FSH resistance Eur J Hum Genet 18 656-661

Kumar T R, Wang Y, Lu N and Matzuk M M (1997) Follicle stimulating hormone is required for ovarian follicle maturation but not male fertility Nat Genet 15 201-214
Laven J S, Mulders A G, Suryandari D A, Gromoll J, Nieschlag E, Fauser B C and Simoni M (2003) Follicle-stimulating hormone receptor polymorphisms in women with normogonadotropicanovulatory infertility Fertil Steril $\mathbf{8 0}$ 986-992

Lend A K, Belousova A, Haller-Kikkatalo K, Punab M, Poolamets O, Peters M and Salumets A (2010) Follicle-stimulating hormone receptor gene haplotypes and male infertility in Estonian population and meta-analysis Syst Biol Reprod Medi 56 84-90

Leng N, Dattatreyamurty B and Reichert L E Jr (1995) Identification of amino acid residues 300-315 of the rat FSH receptor as a hormone binding domain: evidence for its interaction with specific regions of FSH beta-subunit Biochem Biophys Res Commun $210392-399$

Li Y, Gu A, Yang H, Ding X, Ji G, Lu C, Xia Y, Song L and Wang X (2011) FSH receptor gene polymorphisms in fertile and infertile Han-Chinese males Clinica Chimica Acta 412 1048-1052

Lindau-Shepard B, Brumberg H A, Peterson A J and Dias J A (2001) Reversible immuno neutralization of human follitropin receptor J Reprod Immunol 49 1-19

Lindgren I, Giwercman A, Axelsson J and Lundberg Giwercman Y (2012) Association between follicle-stimulating hormone receptor polymorphisms and reproductive parameters in young men from the general population Pharmacogen Genom 22 667-672

Liu X, DePasquale J A, Griswold M D and Dias J A (1994) Accessibility of rat and human follitropin receptor primary sequence (R265-S296) in situ Endocrinology 135 682-691

Loutradis D, Patsoula E, Minas V, Koussidis G A, Antsaklis A, Michalas S and Makrigiannakis A (2006) FSH receptor gene polymorphisms have a role for different ovarian response to stimulation in patients entering IVF/ICSI-ET programs J Assist Reprod Genet 23 177-184

Ludwig A H, Murawska M, Panek G, Timorek A and Kupryjanczyk J (2009) Androgen, progesterone, and FSH receptor polymorphisms in ovarian cancer risk and outcome Endo Relat Canc 16 1005-1016

Mahale S D, Cavanagh J, Schmidt A, MacColl R and Dias J A (2001) Autologous biological response modification of the gonadotropin receptor J Biol Chem 276 12410-12419

Mann K I， Liu X and Dias J A(2000) Deletion of follicle stimulating hormone (FSH) receptor residues encoded by exon one decreases FSH binding and signaling in the rat Biol Reprod 62 1240-1247

Mazurkiewicz J E, Herrick-Davis K, Barroso M, Ulloa-Aguirre A, Lindau-Shepard B, Thomas R M and Dias J A (2015) 
Single molecule analyses of fully functional fluorescent protein tagged follitropin receptor reveals homodimerization and specific heterodimerization with lutropin receptor Biol Reprod [Epub ahead of print]

Meduri G, Touraine P, Beau I, Lahuna O, Desroches A, VacherLavenu M C, Kuttenn F and Misrahi M (2003) Delayed puberty and primary amenorrhea associated with a novel mutation of the human follicle-stimulating hormone receptor: clinical, histological, and molecular studies J Clin Endocrinol Metab 88 3491-3498

Minegishi T, Nakamura K, Takakura Y, Ibuki Y, Igarashi M and Minegishi T (1991) Cloning and sequencing of human FSH receptor cDNA Biochem Biophys Res Commun 175 11251130

Minegishi T, Igarashi S, Nakamura K, Nakamura M, Tano M, Shinozaki H, Miyamoto K and Ibuki Y (1994) Functional expression of the recombinant human FSH receptor $J$ Endocrinol 141 369-375

Mohiyiddeen L, Newman W G, McBurney H, Mulugeta B, Roberts S A and Nardo L G (2012) Follicle-stimulating hormone receptor gene polymorphisms are not associated with ovarian reserve markers Fertil Steril 97 677-681

Montanelli L, Van Durme J J, Smits G, Bonomi M, Rodien P, Devor E J, Moffat-Wilson K, Pardo L, Vassart G and Costagliola S (2004) Modulation of ligand selectivity associated with activation of the transmembrane region of the human follitropin receptor Mol Endocrinol 18 20612073

Morón F J and Ruiz A (2010) Pharmacogenetics of controlled ovarian hyperstimulation: time to corroborate the clinical utility of FSH receptor genetic markers Pharmacogenomics 11 1613-1618

Nakamura K, Hipkin R W and Ascoli M (1998a)The agonistinduced phosphorylation of the rat follitropin receptormaps to the first and third intracellular loops $\mathrm{Mol}$ Endocrinol 12 580-591

Nakamura K, Krupnick J G, Benovic J L and Ascoli M (1998b) Signaling and phosphorylation-impaired mutants of the rat follitropin receptor reveal an activation- and phosphorylation-independent but arrest independent pathway for internalization J Biol Chem 273 24346-24354

Nakamura Y, Maekawa R, Yamagata Y, Tamura I and Sugino N (2008) A novel mutation in exon8 of the follicle-stimulating hormone receptor in a woman with primary amenorrhea Gynecol Endocrinol 24 708-712

Nakayama T, Kuroi N, Sano M, Tabara Y, Katsuya T, Ogihara T, Makita Y, Hata A, Yamada M and Takahashi N (2006) Mutation of the follicle-stimulating hormone receptor gene 5'-untranslated region associated with female hypertension Hypertension 48 512-518

Nardo L G, Yates A P, Roberts S A, Pemberton P and Laing I (2009) The relationships between AMH, androgens, insulin resistance and basal ovarian follicular status in non-obese subfertile women with and without polycystic ovary syndrome Hum Reprod 24 2917-2923

Nechamen C A and Dias J A (2000) Human follicle stimulating hormone receptor trafficking and hormone binding sites in the amino terminus Mol Cell Endocrinol 166 101-110

Nechamen C A and Dias J A (2003) Point mutations in follitropin receptor result in ER retention Mol Cell Endocrinol 201 123-131

Nieschlag E, Simoni M, Gromoll J and Weinbauer G F (1999) Role of FSH in the regulation of spermatogenesis: clinical aspects Clin Endocrinol (Oxf) 51 139-146

Nishi S, Nakabayashi K, Kobilka B and Hsueh A J (2002) The ectodomain of the luteinizing hormone receptor interacts with exoloop 2 to constrain the transmembrane region: studies using chimeric human and fly receptors $\mathrm{J}$ Biol Chem 277 3958-3964

Nordhoff V, Sonntag B, von Tils D, Götte M, Schüring A N, Gromoll J, Redmann K, Casarini L and Simoni M (2011) Effects of the FSH receptor gene polymorphism p.N680S on cAMP and steroid production in cultured primary human granulosa cells Reprod Biomed Online 23 196-203

Orio F Jr, Ferrarini E, Cascella T, Dimida A, Palomba S, Gianetti E, Colao A, Agretti P, Vitti P, Lombardi G, Pinchera A and Tonacchera M (2006) Genetic analysis of the follicle stimulating hormone receptor gene in women with polycystic ovary syndrome J Endocrinol Invest 29 975982

Overbeek A, Kuijper E A, Hendriks M L, Blankenstein M A, Ketel I J, Twisk J W, Hompes P G, Homburg R and Lambalk C B (2009) Clomiphene citrate resistance in relation to follicle-stimulating hormone receptor Ser680Serpolymorphism in polycystic ovary syndrome Hum Reprod 24 2007-2013

Parmentier M, Libert F, Maenhaut C, Lefort A, Gerard C, Perret J, Van Sande J, Dumont J E and Vassart G (1989) Molecular cloning of the thyrotropin receptor Science 246 16201622

Perez-Mayorga M, Gromoll J, Behre H M, Gassner C, Nieschlag E and Simoni M (2000) Ovarian response to folliclestimulating hormone (FSH) stimulation depends on the FSH receptor genotype J Clin Endocrinol Metab 853365 3369

Pengo M, Ferlin A, Arredi B, Ganz F, Selice R, Garolla A and 
Foresta C (2006) FSH receptor gene polymorphisms in fertile and infertile Italian men RBM Online 13 795-800

Pierce J G and Parsons T F (1981) Glycoprotein hormones: structure and function Annu Rev Biochem 50 465-495

Quintana J, Hipkin R W, Sanchez-Yague J and Ascoli M (1994) Follitropin (FSH) and a phorbol ester stimulate the phosphorylation of the FSH receptor in intact cells $J$ Biol Chem $2698772-8779$

Rao A J, Ramachandra S G, Ramesh V, Couture L, Abdennebi L, Salesse R and Remy J J (2004) Induction of infertility in adult male bonnet monkeys by immunization with phageexpressed peptides of the extracellular domain of FSH receptor Reprod Biomed Online 8 385-391

Remy J J, Lahbib-Mansais Y, Yerle M, Bozon V, Couture L, Pajot E, Gréber D and Salesse R (1995) The porcine follitropin receptor: cDNA cloning, functional expression and chromosomal localization of the gene Gene 163257 261

Remy J J, Couture L, Rabesona H, Haertle T and Salesse R (1996) Immunization against exon 1 decapeptides from the lutropin/choriogonadotropin receptor or the follitropin receptor as potential male contraceptive J Reprod Immunol 32 37-54

Richards J S and Midgley A R (1976) Protein hormone action: a key tounderstanding ovarian follicular and luteal cell development Biol Reprod 14 82-94

Rousseau-Merck M F, Atger M, Loosfelt H, Milgrom E and Berger R (1993) The chromosomal localization of the human follicle-stimulating hormone receptor gene (FSHR) on 2p21-p16 is similar to that of the luteinizing hormone receptor gene Genomics 15 222-224

Ryan L, Feng X, d'Alva B, Zhang M, Van Voorhis J and Pinto M (2007) Evaluating the roles of follicle-stimulating hormone receptor polymorphisms in gonadal hyperstimulation associated with sever juvenile primary hypothyroidism $J$ Clin Endocrinol Metab 92 2312-2317

Ryu K, Gilchrist R L, Tung C S, Ji I and Ji T H (1998) High affinity hormone binding to the extracellular N-terminal exodomain of the follicle-stimulating hormone receptor is critically modulated by exoloop 3 J Biol Chem 27328953 28958

Shen Y, Wang L, Zhao Y, You L, Geng L, Gu H F and Chen Z J (2011) Evaluation of the association between GHR exon 3 polymorphism and polycystic ovary syndrome among Han Chinese women Growth Hormon IGF Res 21 248251

Simoni M and Nieschlag E (1995) FSH in therapy: Physiological basis, new preparations and clinical use Reprod Med Rev 4
163-177

Simoni M, Weinbauer F, Gromoll J and Nieschlag E (1999) Role of FSH in male gonadal function Ann Endocrinol 60 102106

Smits G, Olatunbosun O, Delbaere A, Pierson R, Vassart G and Costagliola S (2003) Ovarian hyperstimulation syndrome due to a mutation in the follicle-stimulating hormone receptor N Engl J Med 349 760-766

Sohn J, Ryu K, Sievert G, Jeoung M, Ji I and Ji T H (2002) Follicle-stimulating hormone interacts with exoloop 3 of the receptor J Biol Chem 277 50165-50175

Sohn J, Youn H, Jeoung M, Koo Y, Yi C, Ji I and Ji T H (2003) Orientation of follicle-stimulating hormone (FSH) subunitscomplexed with the fsh receptor J Biol Chem 278 47868-47876

Song G J, Park Y S, Lee Y S, Lee C C and Kang I S (2002) Alternatively spliced variants of the follicle-stimulating hormone receptor gene in the testis of infertile men Fertil Steril 77 499-504

Sprengel R, Braun T, Nikolics K, Segaloff D L and Seeburg P H (1990) The testicular receptor for follicle stimulating hormone: structure and functional expression of cloned cDNA Mol Endocrinol 4 525-530

Sudo S, Kudo M, Wada S, Sato O, Hsueh J and Fujimoto S (2002) Genetic and functional analyses of polymorphism in the human FSH receptor gene Mol Hum Reprod 8 893-899

Tapanainen J S, Aittomäki K, Min J, Vaskivuo T and Huhtaniemi I T (1997) Men homozygous for an inactivating mutation of the follicle-stimulating hormone (FSH) receptor gene present variable suppression of spermatogenesis and fertility Nat Genet 15 205-206

Tena-Sempere M, Manna P R and Huhtaniemi I (1999) Molecular cloning of the mouse follicle-stimulating hormone receptor complementary deoxyribonucleic acid: functional expression of alternatively spliced variant and receptor inactivation by a $\mathrm{C} 566 \mathrm{~T}$ transition in exon 7 of the coding sequence Biol Reprod 60 1515-1527

Thomas R M, Nechamen C A, Mazurkiewicz J E, Muda M, Palmer S and Dias J A (2007) Follice-stimulating hormone receptor forms oligomers and shows evidence of carboxylterminal proteolytic processing Endocrinology 148 19871995

Thomas R M, Nechamen C A, Mazurkiewicz J E, Ulloa-Aguirre A and Dias J A (2011) The adapter protein APPL1 links FSH receptor to inositol 1,4,5-trisphosphate production and is implicated in intracellular $\mathrm{Ca}(2+)$ mobilization Endocrinology1521691-1701

Tilly L, Kowalski I, Schomberg W and Hsueh J (1992) Apoptosis 
in atretic ovarian follicles is associated with selective decreases in messenger ribonucleic acid transcripts for gonadotropin receptors and cytochrome P450 aromatase Endocrinology 131 1670-1676

Timossi C, Maldonado D, Vizcaíno A, Lindau-Shepard B, Conn PM and Ulloa-Aguirre A (2002) Structural determinants in the second intracellular loop of the human folliclestimulating hormone receptor are involved in $\mathrm{G}(\mathrm{s})$ protein activation Mol Cell Endocrinol 189 157-168

Timossi C, Ortiz-Elizondo C, Pineda D B, Dias J A, Conn P M and Ulloa-Aguirre A(2004) Functional significance of the BBXXB motif reversed present in the cytoplasmic domains of the human follicle-stimulating hormone receptor Mol Cell Endocrinol 223 17-26

Touraine P, Beau I, Gougeon A, Meduri G, Desroches A, Pichard C, Detoeuf M, Paniel B, Prieur M, Zorn J R, Milgrom E, Kuttenn F and Misrahi M (1999)New natural inactivating mutations of the follicle-stimulating hormone receptor: correlations between receptor function and phenotype $\mathrm{Mol}$ Endocrinol 13 1844-1854

Tüttelmann F, Rajpert-De Meyts E, Nieschlag E and Simoni M (2007) Gene polymorphisms and male infertility - a metaanalysis and literature review RBM Online 15 643-658

Uribe A, Zariñán T, Pérez-Solis M A, Gutiérrez-Sagal R, JardónValadez E, Piñeiro A, Dias JA and Ulloa-Aguirre A (2008) Functional and structural roles of conserved cysteine residues in the carboxyl-terminal domain of the folliclestimulating hormone receptor in human embryonic kidney 293 cells Biol Reprod 78 869-882

Valkenburg O 1, Uitterlinden AG, Piersma D, Hofman A, Themmen AP, de Jong F H, Fauser B C and Laven J S (2009) Genetic polymorphisms of GnRH and gonadotrophic hormone receptors affect the phenotype of polycystic ovary syndrome Hum Reprod 24 2014-22

Vasseur C, Rodien P, Beau I, Desroches A, Gérard C, de Poncheville L, Chaplot S, Savagner F, Croué A, Mathieu E, Lahlou N, Descamps P and Misrahi M (2003) A chorionic gonadotropin-sensitive mutation in the follicle-stimulating hormone receptor as a cause of familial gestational spontaneous ovarian hyperstimulation syndrome $N$ Engl J Med 349 753-759

Wu W, Cai H, Sun H, Lu J, Zhao D, Qin Y, Han X, Niu X, Lu C and Xia Y (2012) Follicle stimulating hormone receptor G-29A, 919A >G, 2039A >G polymorphism and the risk of male infertility: a meta-analysis Gene $\mathbf{5 0 5} 388-392$
Wunsch A, Ahda Y, Banaz-YaSar F, Sonntag B, Nieschlag E, Simoni $M$ and Gromoll J (2005) Single-nucleotide polymorphisms in the promoter region influence the expression of the human follicle-stimulating hormone receptor Fertil Steril 84 446-453

Yao Y, Ma C H, Tang H L and Hu Y F (2011) Influence of folliclestimulating hormone receptor (FSHR) Ser680Asn polymorphism on ovarian function and in vitro fertilization outcome: a meta-analysis Mol Genet Metab 103 388-393

Yang C Q 1, Chan K Y, Ngan H Y, Khoo U S, Chiu P M, Chan Q K, Xue W C and Cheung A N (2006) Single nucleotide polymorphisms of follicle-stimulating hormone receptor are associated with ovarian cancer susceptibility Carcinogenesis 27 1502-6

Yarney T A, Sairam M R, Khan H, Ravindranath N, Payne S and Seidah N G (1993) Molecular cloning and expression of the ovine testicular follicle stimulating hormone receptor Mol Cell Endocrinol 93 219-226

Zalewski G, WolczyXski S and Chyczewski L (2013) Association of rs6166 polymorphism with FSH receptor transcript variants and steroid production in human granulosa cell cultures Syst Biol Reprod Med 59 191-198

Zariñán T, Perez-Solís M A, Maya-Núñez G, Casas-González P, Conn P M, Dias J A and Ulloa-Aguirre A (2010) Dominant negative effects of human follicle-stimulating hormone receptor expression-deficient mutants on wild-type receptor cell surface expression. Rescue of oligomerizationdependent defective receptor expression by using cognate decoys Mol Cell Endocrinol 321 112-122

Zhang C W, Zhang X L, Xia Y J, Cao Y X, Wang W J, Xu P, Che Y N, Wu X K, Yi L, Gao Q and Wang Y (2012) Association between polymorphisms of the CYP11A1 gene and polycystic ovary syndrome in Chinese women $\mathrm{Mol} \mathrm{Biol}$ Rep 39 8379-8385

Zhang S B, Dattatreyamurty B and Reichert L E (1991) Differential roles of high and low affinity guanosine 5'triphosphate binding sites in the regulation of folliclestimulating hormone binding to receptor and signal transduction in bovine calf testis membranes Endocrinology 128 295-302

Zijlstra-Westhoff W E, Slootstra J W, Puijk W C, Schaaper W M, Oonk H B and Meloen R H (1998) In vitro inhibition of the bioactivity of follicle-stimulating hormone by antisera against a peptide representing part of the FSH-receptor $J$ Reprod Immunol 38 139-154. 